大黒鼠脳組織呼吸の活性化エネルギー

\author{
第 2 篇 \\ 未処置大黒鼠全脳ホモシネート呼吸䣼素系の活性化 \\ エネルギーに及将す $\mathrm{NaCN}$ 添加の影響につレて \\ 岡山大学医学部神程精神医学致室（主任：奥村敉授）
}

薄 井省 吾

[昭和 32 年 9 月 12 日受䅬]

楮蒿

わたくしは第 1 篇に詻いて, ワールフルク 検圧法を用いて，未処置大黒鼠全脳ホモシネ ート呼吸酻素系の活性化エネルギーを測定し， それについて多少の考察を加えて見た，本篇 に括いてはこれに適当な濃度の $\mathrm{NaCN}$ を添 如する事によつて，その值にいかなる变動が 起るかを追求し，得られた值の意義について 検討を加えて見たい。

\section{算出方 法}

第 1 篇に記載した通りである.

\section{実 方跧 法}

大体第 1 篇に述べた通りであるが，特に注 意すべき点だけ記載する事とする，检圧計容 器内容は次の通りである.

主室 : 大黑鼠全脳の $0.2 \%$ 葡萄糖加 KrebsRinger 燐酸䌅衝液による䄪 15 倍木モ シネート $2 \mathrm{ml}$

副室 : $2096 \mathrm{KOH}$ 中約 $4 \times 10^{-4} \mathrm{MKなるよ了}$

飞 NaCN を溶かした百の $0.2 \mathrm{ml}$ 侧室 : $\mathrm{NaCN}$ の $0.9 \% \mathrm{NaCl}$ 溶液 $0.4 \mathrm{ml}$

（添加後の溚度が $4 \times 10^{-4} \mathrm{M}$ となるよ 5 Kし た. この程度の添加は $\mathrm{pH}$ に大きな変化を 及任さない)

気相 : 空気

このさい同一の大黒鼠について，第 1 篇に 記载した容器内容のるの，すなわち $\mathrm{NaCN}$
（一）の系を，同時に対照として測定して居 り，その成績が第 1 篇の表 2 ，表 3 ，表 7 ，表 8 ， 圀3，図4，であり，园4より算出された 值が約 $11000 \mathrm{cal}$.であつた，第 1 篇の系は 側室 (一) であるか，側室より $0.4 \mathrm{ml} の 0.9$ 96 NaCN を添加する事は，予備実験で酸素 吸收量に変化を与えない事を確めてあり，し たがつて真の意味の対照と考克るととができ る、本篇においてる，できる限り複試験を用 いて成績の正確さを期した事はい5までるな い.ここに特に注意すべき事は $\mathrm{NaCN} の$ 濃 度の問題で, 副室のアルカリとして20\% $\mathrm{KOH}$ K約 $4 \times 10^{-4} \mathrm{M}$ K相当する $\mathrm{NaCN}$ を加 光たすのを使用し，CN 蒸気を副室中吸收 して，各実験每作用条件の変る事を防いで いるが，このような条件の下でるホモジー ト中で実際に作用する CN の濃度はその解離 率の異なる為，䈆密には一定しないことを既 飞 Riggs が指摘して居り, $4 \times 10^{-4} \mathrm{M}$ という $\mathrm{NaCN}$ の添加後の㬊度は計算上のるのである 事を附言して拓く。

試料の調製．第 1 篇に述べたと全く同一.

\section{実 酫 成 繶}

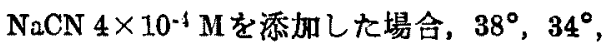
$30^{\circ} \mathrm{C}$ 及び $38^{\circ}, 36^{\circ}, 32^{\circ} \mathrm{C}$ の夫々 1 連の 3 温 度に括いての酸素吸收量を表示すれば表 1 ， 表 2 の゙とくである.

このさい既述のよ 5 K，第 1 篇の表 3 ，表. 2 が夫ふ表 1，表 2 飞対照となつているわけ 
表 $1 \mathrm{NaCN} 4 \times 10^{-4} \mathrm{M}$ 添加した時の酸素吸收量

\begin{tabular}{|c|c|c|c|c|c|c|c|c|c|c|c|c|c|c|c|}
\hline & \multicolumn{3}{|c|}{$x$} & \multicolumn{3}{|c|}{$※$} & \multicolumn{3}{|c|}{$\Delta$} & \multicolumn{3}{|c|}{$\Delta$} & \multicolumn{3}{|c|}{ - } \\
\hline & $38^{\circ} \mathrm{C}$ & $34^{\circ} \mathrm{C}$ & $30^{\circ} \mathrm{C}$ & $38^{\circ} \mathrm{C}$ & $34^{\circ} \mathrm{C}$ & $30^{\circ} \mathrm{C}$ & $38^{\circ} \mathrm{C}$ & $34^{\circ} \mathrm{C}$ & $30^{\circ} \mathrm{C}$ & $38^{\circ} \mathrm{C}$ & $34^{\circ} \mathrm{C}$ & $30^{\circ} \mathrm{C}$ & $38^{\circ} \mathrm{C}$ & $34^{\circ} \mathrm{C}$ & \\
\hline $10^{\prime}$ & $\begin{array}{r}\mu \mathrm{I} \\
16.2\end{array}$ & $\begin{array}{r}\mu 1 \\
11.3\end{array}$ & & $\begin{array}{r}\mu 1 \\
10.9\end{array}$ & $\begin{array}{r}\mu 1 \\
7.6\end{array}$ & $\begin{array}{r}\mu 1 \\
4.7\end{array}$ & $\begin{array}{r}\mu 1 \\
11.6\end{array}$ & $\begin{array}{r}\mu \mathrm{l} \\
8.7\end{array}$ & 6.5 & $\begin{array}{r}\mu 1 \\
15.9\end{array}$ & $\begin{array}{r}\mu 1 \\
11.9\end{array}$ & ${ }^{\mu} .7$ & ${ }_{16.1}^{\mu l}$ & $\begin{array}{r}\mu 1 \\
11.4\end{array}$ & \\
\hline $20^{\circ}$ & 40.1 & 30.1 & 20.5 & 27.2 & 18.4 & 13.7 & 32.7 & 23.3 & 16.4 & 37.9 & 25.2 & 18.6 & 38.9 & 27.4 & \\
\hline $30^{\prime}$ & 63.9 & 46.3 & 33.2 & 43.1 & 29.1 & 20.1 & 48.8 & 33.5 & 23.9 & 58.5 & 39.5 & 29.8 & 61.3 & 41.2 & \\
\hline $40^{\prime}$ & 86.7 & 59.7 & 42.1 & 57.3 & 37.4 & 27.3 & 67.3 & 45.8 & 33.4 & 76.7 & 51.8 & 40.1 & 80.2 & 54.1 & \\
\hline $50^{\circ}$ & 108.5 & 74.5 & 54.3 & 71.9 & 49.1 & 36.1 & 84.3 & 57.3 & 42.2 & 95.1 & 67.2 & 48.0 & 101.6 & 70.8 & \\
\hline $60^{\prime}$ & 129.7 & 89.0 & 67.3 & 87.7 & 59.8 & 43.7 & 102.1 & 70.3 & 51.2 & 116.5 & 81.6 & 59.5 & 122.1 & 86.9 & \\
\hline$\widehat{\Xi}$ & 둑 & 疍莒 & 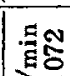 & 䀅哭 & 音害 & 員含 & 曺造 & 苗装 & : & 殉目 & 표 풀 & 曾悉 & 藕 & 夢。 & \\
\hline & 20. & s-i & $\exists-i$ & $\exists-1$ & $\$ 0$ & 10 & $\vec{\nabla}$ & $\exists-$ & $\$^{\circ}$ & छे & $\vec{\xi}-i$ & $0^{\circ}$ & $\bar{z}^{N}$ & $\exists-i$ & \\
\hline
\end{tabular}

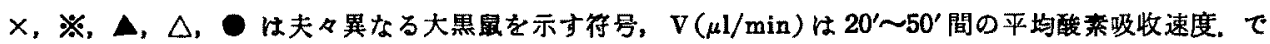
第 1 篇の表 3 の同一符号の示す大黒鼠と同一である.

表 $2 \mathrm{NaCN} 4 \times 10^{-4} \mathrm{M}$ 添加時の酸素吸收量

\begin{tabular}{|c|c|c|c|c|c|c|c|c|c|}
\hline & \multicolumn{3}{|c|}{$\mathbf{0}$} & \multicolumn{3}{|c|}{$\square$} & \multicolumn{3}{|c|}{0} \\
\hline & $38^{\circ} \mathrm{C}$ & $36^{\circ} \mathrm{C}$ & $32^{\circ} \mathrm{C}$ & $38^{\circ} \mathrm{C}$ & $36^{\circ} \mathrm{C}$ & $32^{\circ} \mathrm{C}$ & $38^{\circ} \mathrm{C}$ & $36^{\circ} \mathrm{C}$ & $32^{\circ} \mathrm{C}$ \\
\hline $10^{\prime}$ & $10.9^{\mu l}$ & $8.8^{\mu l}$ & $7.7^{\mu 1}$ & $13.7^{\mu 1}$ & $11.2^{\mu l}$ & $6.4^{\mu 1}$ & $15.2^{\mu 1}$ & $14 . i^{\mu 1}$ & $7.5^{\mu 1}$ \\
\hline $20^{\prime}$ & 28.9 & 24.7 & 16.4 & 35.5 & 27.2 & 20.3 & 36.7 & 29.7 & 22.1 \\
\hline $30^{\prime}$ & 44.2 & 34.2 & 25.8 & 51.8 & 40.9 & 30.1 & 54.8 & 45.2 & 31.8 \\
\hline $40^{\prime}$ & 57.5 & 46.1 & 31.9 & 68.7 & 56.5 & 42.1 & 75.9 & 58.3 & 42.5 \\
\hline $50^{\prime}$ & 73.8 & 58.5 & 41.7 & 89.4 & 70.8 & 53.8 & 91.9 & 72.4 & 56.4 \\
\hline $60^{\prime}$ & 88.9 & 72.3 & 47.4 & 108.8 & 84.9 & 66.2 & 110.6 & 87.2 & 66.1 \\
\hline $\begin{array}{c}\text { 平均速度 } \\
\mathrm{v}(\mu \mathrm{l} / \mathrm{min})\end{array}$ & $\begin{array}{l}\mu 1 / \min \\
1.460\end{array}$ & $\begin{array}{l}\mu 1 / \min \\
1.168\end{array}$ & $\begin{array}{l}\mu \mathrm{l} / \mathrm{min} \\
0.827\end{array}$ & $\begin{array}{l}\mu 1 / \mathrm{min} \\
1.753\end{array}$ & $\begin{array}{l}\mu \mathrm{l} / \mathrm{min} \\
1.396\end{array}$ & $\begin{array}{l}\mu 1 / \min \\
1.045\end{array}$ & $\begin{array}{l}\mu 1 / \min \\
1.852\end{array}$ & $\begin{array}{l}\mu 1 / \min \\
1.469\end{array}$ & $\begin{array}{l}\mu 1 / \min \\
1.091\end{array}$ \\
\hline
\end{tabular}

ロ，口，○壮夫々異なる大曊鼠を示す符号で第 1 籍の表 2 の同一符号の示す大黒最と同一である. $\mathrm{V}(\mu \mathrm{l} / \mathrm{min})$ अ $20^{\prime} \sim 50^{\prime}$ 間の平均酸箱吸收速度.

である．但第 1 篇の表 3 ，表 2 の示すダータ 一は測室日であり，したがつて本篇の表 1 ，表 2 の場合の実験条件より $0.9 \% \mathrm{NaCl} 0.4 \mathrm{cc}$ だけ少く，全く同一条件の対照とは云い得な いが，予俑実験で 0.9 名 $\mathrm{NaCl} 0.4 \mathrm{cc}$ の有無 は酸絮吸收速度に影響を与えないことを確め てあり，真の意味の対照と見做し得るもので ある，表1，表 2 亿おいて，最初の 10 分間の 酸素吸收昷が各温度期なり低く，20分～50 分のそれが比較的直線飞近い均一な吸收速度 を示す事は，かなり明らかにしめされている が，表 1，表 2，から各 1 例をぬいて図示す ると四1，図2，のごとくであつて，その傾 向が 1 目膫然となる。従つてVは20分〜50分
間の平均酸素吸收速度を採用した。すなわち $20^{\prime} ， 30^{\prime} ， 40^{\prime} ， 50^{\prime}$ 目の酸素吸收量の総和を 140 分間に平均して算出したるのである，実 験に供した 8 匹の大黒鼠の $38^{\circ} \mathrm{C}$ に甜ける酸 掏吸收速度は $\mathrm{NaCN} 4 \times 10^{-4} \mathrm{M}$ の添如火より， 表 3 K明らかなよ 5 K最低約14\%から最高約 35\%におよぶ低下を示して居り，かなりの動 播が見られる。

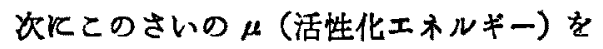
算出してみよう，表 1，表 2，飞記载した V の対数を表示したるのが表 $1^{\prime}$ ，表 $2^{\prime}$ である. 表 $1^{\prime}$ ，表 2'よりその $\log \mathrm{V}$ を縦軸に，1/T を横軸炕目盛つたるのが図3であり，因3の 夫々の点を縦軸にそつて適当に移動して作図 
図 1

×（表1の）を図示したすの

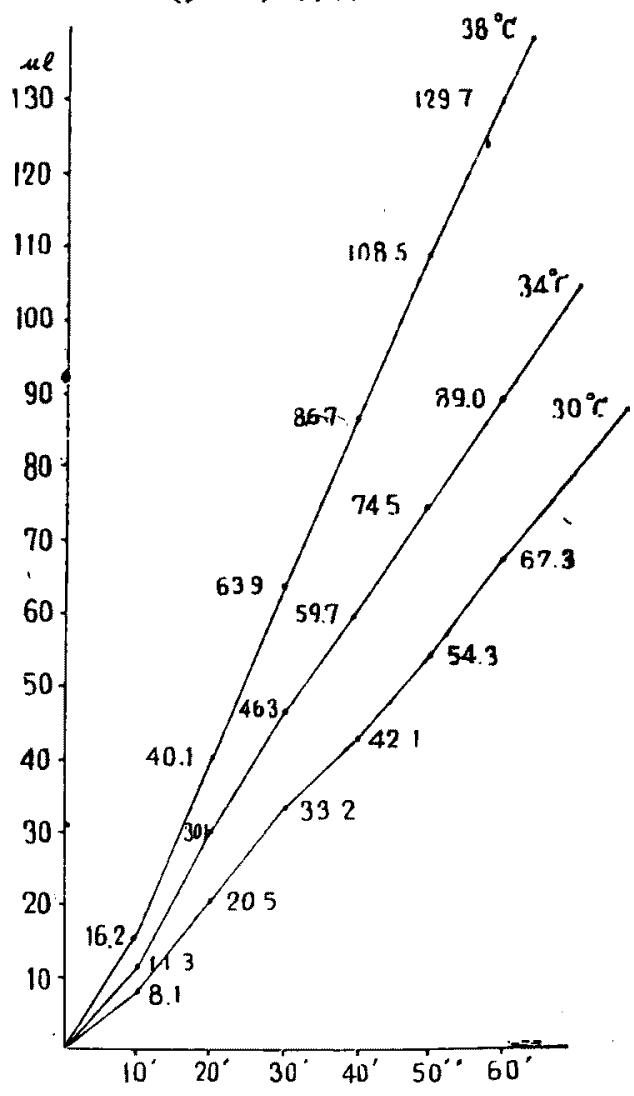

表 3

\begin{tabular}{|c|c|c|c|c|c|}
\hline & \multicolumn{2}{|c|}{ Kontrol } & \multicolumn{2}{|c|}{$\begin{array}{l}\mathrm{NaCN} 4 \times 10^{-4} \mathrm{M} \\
\text { 添 }\end{array}$} & 低下率 \\
\hline$x$ & $\begin{array}{l}\mu 1 / \min \\
2.476\end{array}$ & $100 \%$ & $\begin{array}{l}\mu \mathrm{l} / \mathrm{min} \\
2.137\end{array}$ & $\begin{array}{r}\mathrm{Ca} \\
86 \%\end{array}$ & $\begin{array}{r}\mathrm{Ca} \\
14 \%\end{array}$ \\
\hline$\Delta$ & 2.223 & $100 \%$ & 1.916 & $86 \%$ & $14 \%$ \\
\hline - & 2.641 & $100 \%$ & 2.014 & $76 \%$ & $24 \%$ \\
\hline O & 2.444 & $100 \%$ & 1.852 & $76 \%$ & $24 \%$ \\
\hline a & 1.971 & $100 \%$ & 1.460 & 7496 & $26 \%$ \\
\hline$\square$ & 2.414 & $100 \%$ & 1.753 & 7396 & $27 \%$ \\
\hline$\Delta$ & 2.357 & $100 \%$ & 1.665 & $71 \%$ & $29 \%$ \\
\hline & 2.183 & $100 \%$ & 1.425 & $65 \%$ & $35 \%$ \\
\hline
\end{tabular}

（註 $\mathrm{NaCN}$ の添加浱度を選定すると当つては，先ず 予储実験として種々の灌度の NaUN の添加を行い， 平均20\%前後の呼吸低下を来す签度を選択したもの である)

したすのが図4である。（集，移動方法は図 4 亿記载してある通りで，此の図中に用いら れた符号は表中に用いられたすのと同一)
目 2

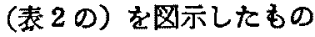

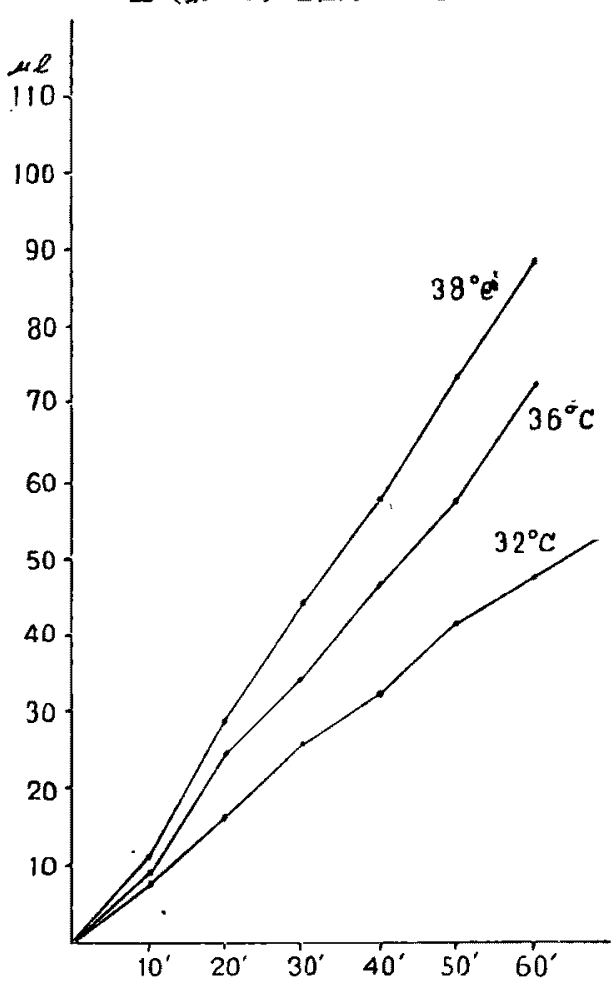

表 $1^{\prime} \log \mathrm{V}$

\begin{tabular}{|c|c|c|c|c|c|c|}
\hline \multirow[b]{2}{*}{$x$} & \multicolumn{2}{|r|}{$38^{\circ} \mathrm{C}$} & \multicolumn{2}{|c|}{$34^{\circ} \mathrm{C}$} & \multicolumn{2}{|c|}{$30^{\circ} \mathrm{C}$} \\
\hline & $\left|\begin{array}{l}\mathrm{V} \\
\log \mathrm{V}\end{array}\right|$ & $\mid \begin{array}{l}\mu \mathrm{l} / \mathrm{min} \\
2.137 \\
0.3298\end{array}$ & $\left|\begin{array}{l}\mathrm{V} \\
\log \mathrm{V}\end{array}\right|$ & $\begin{array}{l}\mu 1 / \mathrm{min} \\
1.504 \\
0.1772\end{array}$ & $\begin{array}{l}\mathrm{v} \\
\log \mathrm{V}\end{array}$ & \\
\hline ※ & $\left|\begin{array}{l}V \\
\log V\end{array}\right|$ & \begin{tabular}{|l|}
$\mu \mathrm{l} / \mathrm{min}$ \\
1.425 \\
0.1538 \\
\end{tabular} & $\left|\begin{array}{l}V \\
\log V\end{array}\right|$ & $\begin{array}{c}\mu 1 / \mathrm{min} \\
0.957 \\
-0.0191 \\
\end{array}$ & $\left|\begin{array}{l}V \\
\log v\end{array}\right|$ & $\begin{array}{r}0.696 \\
-0.1586\end{array}$ \\
\hline$\Delta$ & $\begin{array}{l}V \\
\log V\end{array}$ & & $\left|\begin{array}{l}v \\
\log v\end{array}\right|$ & $\begin{array}{r}\mu 1 / \min \mid \\
1.142 \\
0.0577\end{array}$ & $\begin{array}{l}v \\
\log v\end{array}$ & $\begin{array}{r}\mu \mathrm{l} / \mathrm{mi} \\
0.82 \\
-0.0819\end{array}$ \\
\hline$\Delta$ & $\mid \begin{array}{l}V \\
\log V\end{array}$ & $\begin{array}{l}\mu 1 / \mathrm{min} \\
1.916 \\
0.2824\end{array}$ & $\left|\begin{array}{l}v \\
\log v\end{array}\right|$ & $\begin{array}{r}\mu 1 / \mathrm{min} \\
1.312 \\
0.1179\end{array}$ & $\begin{array}{l}V \\
\log V\end{array}$ & $\begin{array}{r}\mu \mathrm{l} / \overline{\mathrm{min}} \\
0.975 \\
-0.0110\end{array}$ \\
\hline & $\begin{array}{l}V \\
\log V\end{array}$ & $\begin{array}{c}\mu 1 / \min \\
2.014 \\
0.3041\end{array}$ & $\mid \begin{array}{l}V \\
\log V\end{array}$ & $\checkmark \begin{array}{c}\mu 1 / \min \\
1.382 \\
0.1405\end{array}$ & $\mid \begin{array}{l}v \\
\log \end{array}$ & $\mu \mathrm{l} / \mathrm{min}$ \\
\hline
\end{tabular}

四4亿明らかなように， $\mu$ の值を算出すると 約 $15800 \mathrm{cal}$. となる 
表 $2^{\prime} \log \mathrm{V}$

\begin{tabular}{|c|c|c|c|c|c|c|}
\hline & \multicolumn{2}{|c|}{$38^{\circ} \mathrm{C}$} & \multicolumn{2}{|c|}{$34^{\circ} \mathrm{C}$} & \multicolumn{2}{|r|}{$30^{\circ} \mathrm{C}$} \\
\hline 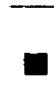 & $\begin{array}{l}V \\
\log V\end{array}$ & $\begin{array}{c}\mu 1 / \min \\
1.460 \\
0.1644\end{array}$ & $\begin{array}{l}V \\
\log V\end{array}$ & $\begin{array}{c}\mu 1 / \mathrm{min} \\
1.168 \\
0.0674\end{array}$ & $\begin{array}{l}\mathrm{V} \\
\log \mathrm{V}\end{array}$ & $\mid \begin{array}{c}\mu 1 / \mathrm{min} \\
0.827 \\
-0.0825\end{array}$ \\
\hline$\square$ & $\begin{array}{l}V \\
\log V\end{array}$ & $\begin{array}{c}\mu 1 / \mathrm{min} \\
1.753 \\
0.2438\end{array}$ & $\begin{array}{l}V \\
\log V\end{array}$ & $\begin{array}{c}\mu l / \min \\
1.396 \\
0.1449\end{array}$ & $\begin{array}{l}V \\
\log V\end{array}$ & $\begin{array}{c}\mu 1 / \min \\
1.045 \\
0.0191\end{array}$ \\
\hline 0 & $\begin{array}{l}V \\
\log V\end{array}$ & $\begin{array}{c}\mu 1 / \min \\
1.852 \\
0.2676\end{array}$ & $\begin{array}{l}V \\
\log V\end{array}$ & $\begin{array}{c}\mu 1 / \min \\
1.469 \\
0.1670\end{array}$ & $\begin{array}{l}V \\
\log V\end{array}$ & $\begin{array}{c}\mu 1 / \min \\
1.091 \\
0.0378\end{array}$ \\
\hline
\end{tabular}

表 $1^{\prime}$, 表 $210 \log \mathrm{V}$ 蛙少数第 5 位で 4 捨 5 入乙 ている.

国 $3 \mathrm{NaCN} 4 \times 10^{-4} \mathrm{M}$ 添加

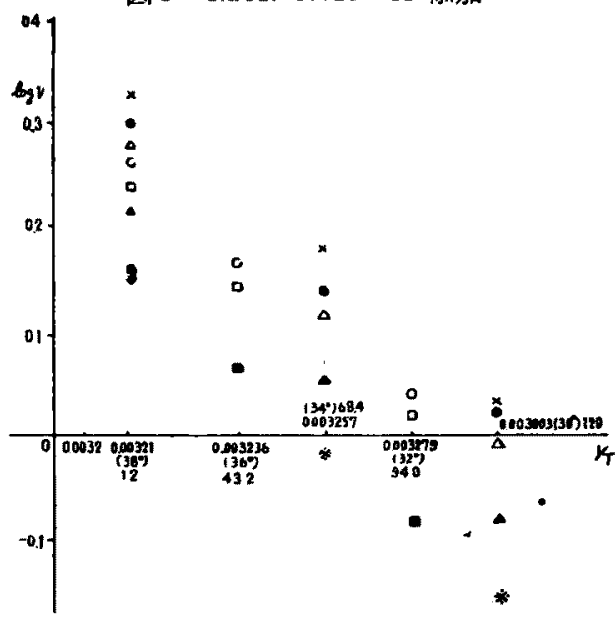

図 $4 \mathrm{NaCN} 4 \times 10-4 \mathrm{M}$ 添加

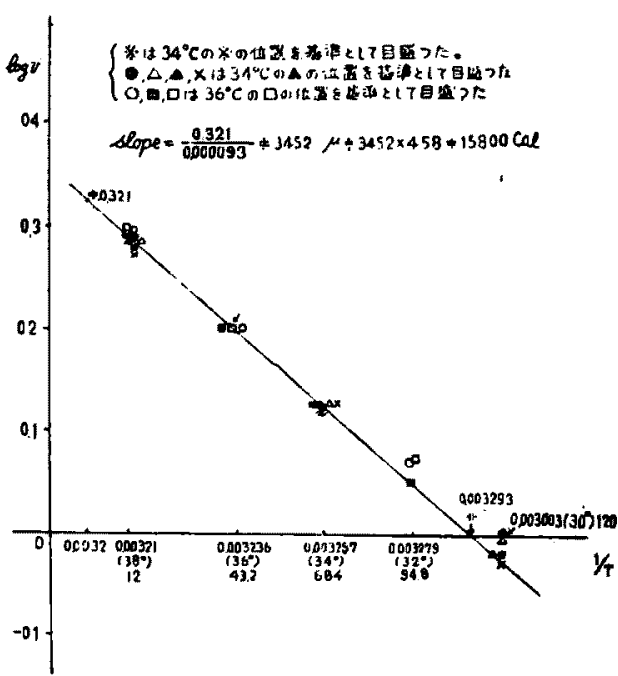

（註）图 4 K於いて同じ高さに横に並えでいる諸点 は同一の位置飞重なるべきるのを作図の都合 上横に目盛つたむのである。
考察

第1篇において記述したように，呼吸飞対 乙て約 16000 cal., (A)， 11000 cal. (B)，約 $8000 \mathrm{cal}$. (C).の 3 主要值が存在してをり， 本篇飞括いて $\mathrm{NaCN} 4 \times 10^{-4} \mathrm{M}$ を添加した場 合の大黒鼠全脳ホモシネートの活性化エネル キーは約15800 cal. となつて括り，とれはワ 一ルフルク検压法の精度と算出方法を併せ考

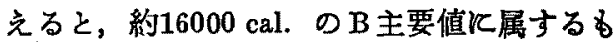
のと思われる. Hoagland は牛心筋より抽出 した坬珀酸酸化酵素系 ( $\mathrm{pH} .7 .4$ の燐酸緩 衝液, $24^{\circ} \sim 40^{\circ} \mathrm{C}$, Substrate: Succinate) $k$ 扣いては，琥的酸脱水素酳素系が律速反応と なつて括り，その

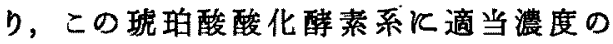
$\mathrm{NaCN}$ を添加した場合，その梳約 $16000 \mathrm{cal}$. 飞変化しこれはチトクローム，チトクロー ムオキンダーゼ系が律速反応に転換した為で あるとしている。

シアン化合物の呼吸阻害は主としてキトク ローム・オキンダーゼに対する阻害作用によ るものである事は，Warburg の研究以来明 らかにされて括り，本篇の実験条件の下での わたくしの成績に招いても， $\mathrm{NaCN} 4 \times 10^{-4}$ $\mathrm{M}$ の添加は $38^{\circ} \mathrm{C}$ 飞括いて，大黒鼠全脳木モ シネートの酸素吸收速度を約 $14 \%$ 約 $35 \%$ 低下させて括り，且無添加時の $\mu$ 約 $11000 \pm$ 500 cal. が約 15800 cal. K転換しているが, これはナトクローム・オキンターゼの阻害 によるすのとみなす事ができる、Fetを $\mathrm{Fe}^{+++}$飞酸化する時の $\mu$ の值が $16200 \pm$ cal. であるという事は古くから知られて扣り，又 多くの細胞呼吸道程飞扔いて，鉄飞触媒され る道程が姿々律速反虑となる事が，直接の化 学的方法で証明されている．以上の事実より 本篇の約 $16000 \mathrm{cal}$. という $\mu$ の值は，テト クローム・チトクロームオキシターーセ系が律 速反沁となつた時のものであると推定してす 差支ないすのと考劣られる。 


\section{結}

論

わたくしは大黒鼠全脳ホモジートの呼吸 の活性化エネルキーに及活す $\mathrm{NaCN} 4 \times 10^{-4} \mathrm{M}$ 添加の影響を検討し，次のような結果を得 た.

(1) $\mathrm{NaCN} 4 \times 10^{-4} \mathrm{M}$ 添加時酸素吸收速度
は約1496〜35\%の低下を来し，活性化エネル ギーは約 $15800 \mathrm{cal}$. 亿乾換する゙

(2) 此の活性化エネルギー值は約 $16000 \mathrm{cal}$. と同一視してょく，チトクローム・チトクロ 一ム酸化醉素系が律速反応になつた為と考觉 られる.

文献：第 3 篇に揭げる.

\title{
Activation Energy for Rat's Brain Tissue Respiration
}

II.

\author{
Influence of $\mathrm{NaCN}$ Addition On Activation Energy for Respiration \\ Enzyme System of Untreated Rat's Whole Brain Homogenate.
}

By

Seigo Usui

Department of Neurology \& Psychiatry, Okayama University Medical School

(Director: Prof. N. Okumura)

By studying the effects of $\mathrm{NaCN} 4 \times 10^{-4} \mathrm{M}$ on the activation energy of whole brain homogenate of rats, the following results were obtained: namely, the rate of oxygen absorption at the time when $\mathrm{NaCN}_{4} \times 10^{-4} \mathrm{M}$ is loaded decreases about $14-35$ per cent, while the activation energy increases up to about $15,800 \mathrm{cal}$. This value can be considered as almost equivalent to 16,000 cal., and it seems to be due to the cytochrom. cytochrom-oxidase system has turned to the rate determining reaction. 